\title{
Publicações do Serviço de Documentação do D.A.S.P.
}

\section{OBRAS EDITADAS A PARTIR DE 1965}

Circulares da Presidência da República — de 1962 a 1963.

Circulares da Presidência da República — de 1964.

Promoção e Acesso - Decretos números 53.480 e 54.488 , ambos de 1964.

Prontuário de Redação Oficial - João Luiz Ney $-4^{2}$ edição.

História Administrativa do Brasil - Volume I - Helio de Alcântara Avellar e Alfredo D'Escragnolle Taunay - $2^{3}$ edição.

Estatuto dos Funcionários Civis da União e Legislação Regulamentadora - Lei $\mathrm{n}^{\circ} 1.711$, de 28 de outubro de 1952.

Regimento do DASP - Aprovado pelo Decreto $\mathrm{n}^{\circ} 50.679$, de 31 de maio de $1961,3^{\text {a }}$ edição.

O Departamento de Referência - Tradução de Sylvio do Valle Amaral (Charles F. McCombs) $4^{a}$ edição.

Enquadramento e Readaptação - $\mathrm{Pa}$ receres da Comissão de Classificação de Cargos - Waldyr dos Santos.

Noşöes Básicas de Análise - João Luiz Ney.

Formação Profissional: Fórmulas Ideais - Estanislau Fischlowitz.

Mantual de Servico dos Processos das Pensões Civis do Tesouro Nacional - Série Manuais de Serviço Wanderley T. Viana e Olavo P. Pinto.
$D A S P$ - Organização funcional e localização de órgãos sediados na Capital Federal e dos Representantes nos Estados (Nomes, Endereços e Telefones).

Ótgãos da Administração Federal (Arrolamentos e subordinação, incluindo: Interpol, Poder Legislativo e Poder Judiciário) .

Promoção, Acesso, Transferência e Remoção dos Funcionários Públicos Civis da União - Decretos números 53.480 , de $23-1-64 ; 54.488$, de 15-10-64 e 53.481, de 23-1-64.

Circular $n^{0} 18$ - Secretaria da Presidência da República. Seção de $\mathrm{Pu}$ blicaçôes do Serviço de Documentação do DASP - 1965.

Circulares da Presidência da República — de 1959 - 1964 .

Lei $\mathrm{n}^{\circ} 4.345$ de 26-6-964 - Institui novos valôres para os vencimentos dos Servidores Públicos Civis do Poder Executivo e dá outras providências.

Lei $\mathrm{n}^{0}$ 4.348, de 26-6-964 - Estabelece normas processuais relativas a Mandado de Segurança.

Lei $\mathrm{n}^{\circ}$ 4.863, de 29-11-965 - Reajusta os vencimentos dos servidores civis e militares, altera as aliquotas dos impostos de renda, importaçăo, consumo e sêlo e da quota de previdência social, unifica contribuições baseadas nas fôlhas de salário e dá outras providências.

Lei $\mathrm{n}^{\circ} 4.863$, de 29-11-965 - Tabelas de Vencimentos dos Servidores Públicos Federais civis e militares, dos membros do Ministério Público $\mathrm{Fe}$ deral e Serviço Juridico da Unnião, 
inclusive cotas de Salário-Familia, e ainda, tabelas de Funções Gratificadas e Cargos em Comissão - D.O. de 30-11-65 - Suplemento $\mathrm{n}^{\circ} 228$.

Lei $\mathrm{n}^{\circ}$ 1, de 13-11-965 - Institui o Cruzeiro Nôvo e dá outras providências.

Decreto $\mathrm{n}^{9}$ 54.061, de 28-7-964 - Regulamenta o Regime de Tempo Integral previsto nos arts. 11 e 12 da Lei $\mathrm{n}^{\circ} 4.345$, de 26-6-964, e Dec. $\mathrm{n}^{2}$ 56.730, de 16-8-965 - Altera o decreto anterior. D. O. de $17-8$ de 1965.

Decreto n ${ }^{0}$ 56.887, de 20-9-65 - Altera o Regimento da Comissão de Classificação de Cargos - D.O. de 23-9-65 - Seção I.

Lei $n^{0}$ 881-A, de 6-12-965 - Dispõe sôbre o Estatuto do Magistério Superior - D.O. de 10-12-965.

Decreto $n^{\circ}$ 57.630, de 14-1-966 - Dispõe sôbre Nomeação e Admissão de Pessoal para o Serviço Público $\mathrm{Fe}$ deral - D.O. de 17-11-966.

Decreto $n^{0}$ 57.744, de 3-2-966 - Regulamenta o Regime de Tempo Integral e Dedicação Exclusiva - D.O. de 17-2-966.

Decreto $n^{\circ}$ 58.095, de 28-3-966 - Aprova o Regimento da Comissão de Tempo Integral e Dedicação Exclusiva - D.O. de 1-4-966.

Exposição de Motivos $n^{\circ}$ GB-25, de 1 de abril de 1966 - Normas e critérios elaborados pela COTIDE para aferição da essencialidade, complexidade e grau de responsabilidade de atribuições, e para investigação das condições do mercado de trabalho e conseqüentes dificuldades de recrutamento para determinados cargos.
Indice da Revista do Serviço Público do Ano XXIV - 1961 .

Circulares da Presidência da República - Expedidas em 1965.

Estudos de Direito Administrativo Vol. II - Pareceres - Clenicio da Silva Duarte.

O Serviço de Revisão de Provas Tipográticas $-2^{4}$ edição - Francisco Wlasek Filho.

Municipio e Municipalização - $1^{7}$ edição - Manoel de Oliveira Franco Sobrinho.

Censo dos Servidores Públicos Civis da União e das Autarquias - Decreto $\mathrm{n}^{\circ} 58.297$ de 2-5-966 - Estabelece normas para execução do censo dos servidores civis da União e das Autarquias.

Aspectos de Relaçốes Públicas - Sylla M. Chaves - $2^{a}$ edição - Seção de Publicações - S. D. - DAŚP. - 1966.

Manual de Simplificação do Trabalho- José Rodrigues de Senna - $2^{7}$ edição - Seção de Publicações. S. D. - DASP. - 1966.

Ementário de Decisões Administrativas - Pareceres do Consultor-Geral da República, do Consultor Jurídico do DASP e da Divisão do Regime Juridico de Pessoal do DASP -1966.

Estudos de Promoção e Acesso - Série «Ensaios de Administração» n* 21 — José Medeiros - 1966.

Classificação de Cargos de Nivel Superior - Legislação e Jurisprudência atualizada até 30-9-66 - Seção de Publicações - S. D. - DASP - 1966. 